\title{
CORRIGENDUM
}

\section{Corrigendum to VEGF165 and angiopoietin-1 decreased myocardium infarct size through phosphatidylinositol-3 kinase and Bcl-2 pathways}

\author{
L Zhou, W Ma, Z Yang, F Zhang, L Lu, Z Ding, B Ding, T Ha, X Gao and C Li \\ Department of Cardiology, the first affiliated hospital, Nanjing Medical University, Nanjing, China
}

Gene Therapy (2005) 12, 552. doi:10.1038/sj.gt.3302501

Correction to: Gene Therapy (2005) 12, 196-202.

doi:10.1038/sj.gt.3302416

Since publication of the above article, the authors have identified an error in the authorship of the paper. The correct authorship is shown below.

$\mathrm{L}_{\text {Zhou }}{ }^{1}$, W Ma ${ }^{1 *}$, Z Yang ${ }^{1}, \mathrm{~F}$ Zhang ${ }^{1}, \mathrm{~L} \mathrm{Lu}^{1}$, Z Ding ${ }^{1}$, B Ding ${ }^{1}, \mathrm{~T} \mathrm{Ha}^{1}, \mathrm{X} \mathrm{GaO}^{2 *}, \mathrm{C} \mathrm{Li}^{1,3 *}$

${ }^{1}$ Department of Cardiology, the first affiliated hospital, Nanjing Medical University, Nanjing, China

${ }^{2}$ Model Animal Research Center, Nanjing University, Nanjing, China
${ }^{3}$ Department of Surgery, Quillen College of Medicine, East Tennessee State University, USA

*Corresponding authors:

Wenzhu Ma, MD. Leizhou1234@sina.com

Xiang Gao, PhD. gaoxiang@nju.edu.cn

Chuanfu Li, MD. li@access.etsu.edu

This study was supported by the National Institutes of Health (NIH) Grant RO1 HL-071837 (to C Li) and National Gongguan Project of China Grant 2001BA710B (to X Gao).

\section{ERRATUM}

\section{Inhibiting estrogen responses in breast cancer cells using a fusion protein encoding estrogen receptor- $\alpha$ and the transcriptional repressor PLZF}

L Buluwela, J Pike, D Mazhar, T Kamalati, SM Hart, R Al-Jehani, H Yahaya, N Patel, N Sarwarl, DA Heathcote, O Schwickerath, F Phoenix, R Hill, E Aboagye, S Shousha, J Waxman, NR Lemoine, A Zelent, RC Coombes and S Ali

Gene Therapy (2005) 12, 552. doi:10.1038/sj.gt.3302506

Correction to: Gene Therapy (2005) 12, 452-460.

doi: $10.1038 /$ sj.gt.3302421

The above author name was published incorrectly, the correct name is given below:

N Sarwar

The publishers apologise for this error. 